\title{
INPUT AND OUTPUT CONSTRAINTS AFFECTING IRRIGATION DEVELOPMENT
}

\section{G. SCHRAMM}

School of Natural Resources, University of Michigan, Ann Arbor, MI 48109 (U.S.A.)

(Accepted for publication October 10, 1980)

\section{ABSTRACT}

Schramm, G., 1981. Input and output constraints affecting irrigation development. In: L.R. Beard (Guest-Editor), Water for Survival. J. Hydrol., 51: 1-16.

In many of the developing countries the expansion of irrigated agriculture is used as a major development tool for bringing about increases in agricultural output, rural economic growth and income distribution. Apart from constraints imposed by water availability, the major limitations considered to any acceleration of such programs are usually thought to be those of costs and financial resources. However, as is shown on the basis of empirical data drawn from Mexico, in reality the feasibility and effectiveness of such development programs is even more constrained by the lack of specialized physical and human factors on the input and market limitations on the output side. On the input side, the limited availability of complementary factors such as, for example, truly functioning credit systems for small-scale farmers or effective agricultural extension services impose long-term constraints on development. On the output side the limited availability, high risk, and relatively slow growth of markets for high-value crops sharply reduce the usually hoped-for and projected profitable crop mix that would warrant the frequently high costs of irrigation investments. Three conclusions are drawn:

(1) Factors in limited supply have to be shadow-priced to reflect their high opportunity costs in alternative uses.

(2) Re-allocation of financial resources from immediate construction of projects to longer-term increase in the supply of scarce, highly-trained manpower resources are necessary in order to optimize development over time.

(3) Inclusion of high-value, high-income producing crops in the benefit-cost analysis of new projects is inappropriate if these crops could potentially be grown in already existing projects.

\section{INTRODUCTION}

In most developing countries agricultural planning, and, within it, irrigation planning, proceeds initially at the macro-level, with targets established on the basis of expected population growth, food import requirements or export targets, availability of funds, etc. In the case of Mexico, for example, the National Water Plan has analysed likely demands on a macro-basis until the year 2000, and concluded that within that period an approximate doubling of agricultural land subject to water control (irrigation, flood control and drainage) would be needed (S.R.H., 1975, Ch. V). 
Within these general projections, more detailed ones, such as projections of individual commodity needs and a listing of potential project sites may also be included ${ }^{* 1}$. However, beyond these statements and assessments, detailed program and project analysis normally proceeds strictly on a microlevel, i.e. a project-by-project basis. This is understandable, given the quantum jump in qualitative and quantitative information that has to be assembled on a location-specific basis before the feasibility of a specific project can be evaluated. This process takes much time, requires detailed agricultural, engineering and economic analyses, and is subject to many variables that affect the overall time needed to come to a final decision. As a result, the planning and decision process for a project frequently requires many years and, on occasion, a decade or more will pass from first conception to project start-up or final rejection. For all but the smallest and simplest projects two years of planning and preparatory work appears to be the absolute minimum.

The disadvantage of these long lead times is that many of the underlying assumptions, projections and parameters may change, while the evaluation of a given project proceeds. These changes, unfortunately, are rarely taken into account, if only because the terms of reference for a given study are fixed from the outset. Furthermore, because of the necessity to proceed with detailed planning on a case-by-case basis, and because of the uncertainty when a given project may finally be approved and financed, the effects of them on factor or product markets is rarely taken into account. Or if they are taken into account, then the evaluation is limited to an analysis of the individual project's effect on these markets, without reference to the combined effects of all other projects or programs that are realized at the same time elsewhere in the economy. As a consequence, it is often found that assumed availabilities of input factors which are in overall short supply do not materialize, or do so only at highly inflated $\operatorname{costs}^{* 2}$, or in quantitities or qualities that are insufficient for the task at hand (see also Schramm, 1976). On the output side, the effects are frequently that particularly valuable components of projected production do not materialize, because the available markets for these high-value crops have been occupied by others. But even if this is not the case, it can be shown that in many cases the successful development of high-value crops production within a new project does nothing more than to frustrate the expansion of such production elsewhere. This means that this output increment is not a genuine, project-specific addition to national income but an increment achieved through substitution from an existing or potential producer in one region to a new one in another. While these shifts in the location of production may be desirable from an income distributional point of view, in terms of national efficiency objectives the net value of the output achieved is not and should not be counted as a project benefit. The following data, drawn from Mexico, will illuminate these points.

\footnotetext{
*1 Mexico's National Water Plan contains both types of projections.

*2 For a rigorous definition and analysis of the opportunity costs of displaced production see Schramm (1972).
} 
While irrigation has been practiced in Mexico for many centuries, systematic, government supported and financed development began in 1926, when the first Federal irrigation law was promulgated. Today, $\sim 5 \cdot 10^{6}$ ha out of $16.8 \cdot 10^{6}$ ha of agricultural land are irrigated, and the value of agricultural output from irrigated land amounts to somewhat over $50 \%$ of the total (Escamilla et al., 1975). Strong efforts were made by the Mexican government during the 1970's to increase agricultural output in general, both as a means of alleviating rural poverty and unemployment and for the purpose of increasing agricultural output. Investments in new and rehabilitated irrigation projects played an important part in this strategy. While total Federal investment in irrigation projects between 1926 and 1970, a 45-yr. period, resulted in the development of $\sim 2,959,000$ ha, between 1971 and 1974 , or within four years, $\sim 337,000$ ha were added. In addition, some 234,000 ha of existing irrigated land were rehabilitated during the same four-year period (S.R.H., 1975, Vol. II).

Irrigation development proceeds within the framework of two distinct programs, both administered by the Ministry of Water Resources (Secretaria de Recursos Hidraulicos, or S.R.H. ${ }^{* 1}$. The first is responsible for the development or rehabilitation of large-scale irrigation districts which may range in size from a few hundred to several hundred thousand hectares, while the second concentrates on the development of small-size units that may range from a few hectares to a maximum legal size of 2,500 ha, with an average size of less than 200 ha. With an average annual addition or rehabilitation of $150,000-200,000 \mathrm{ha}^{* 2}$ and a planning-construction period of several years for many of the larger projects, it means that several hundred of them are in various stages of planning, evaluation, design or construction at any given time. It is obvious that coordination between the individual departments and groups responsible for these individual projects is a difficult task, the more so because the planning, construction and operating phases of any one project are the responsibility of distinct departments within the S.R.H.

An important characteristic of these developments is that they are designed to aid exclusively small-scale landholders. According to the 1972 Water Law, individual landholdings in new Federally-financed irrigation projects are limited to $20 \mathrm{ha}$. This imposes heavy requirements on outside technical education and extension services, since the majority of these farmers have only limited skills, experience and formal education ${ }^{* 3}$.

\footnotetext{
${ }^{* 1}$ Since the end of 1976 , the activities of S.R.H. have been merged with that of the former Ministry of Agriculture into the Ministry of Agriculture and Hydraulic Resources (S.A.R.H.).

*2 This includes double-cropping.

*3 In $1970,43.6 \%$ of the agricultural population had no formal education, while another 39.1 had only between 1 and 3 yr. of schooling. According to Mexican authorities on the subject, all of them are classified as functional illiterates (Urquidi, 1974).
} 
In addition to irrigation developments, the Mexican government makes other strenuous efforts to improve both output and income in the sector. Particularly noteworthy are large-scale credit programs for the livestock and agro-industrial sectors, as well as major, comprehensive rural development programs that are directed towards the integrated development of some onehundred specially selected micro-regions throughout the country with an average of 10,000 farm families in each ${ }^{* 1}$.

\section{INPUT CONSTRAINTS}

Overall, governmental budget allocations to the agricultural sector in real terms increased more than seven-fold between 1970 and 1975 from $7.6 \%$ of total expenditures to $20.1 \%$ (Escamilla et al., 1975). However, financial resources alone are not enough to achieve the simultaneous goals of increased output and improved income distribution. The latter, in the long run, depends largely on the former*2. But in order to bring about increased production other inputs are needed besides physical infrastructure such as irrigation water, improved road access or agricultural warehouses. A whole series of supporting services must be provided in order to achieve the expected production potential. Such supporting services include availability and timeliness of short- and long-term credit; and of fertilizers, seeds and insecticides; accessibility to markets and marketing facilities; and the availability of effective agricultural research and extension services. All of these ancillary services depend on the availability and functioning of relatively complex humanoperated delivery systems.

The importance of these supporting services has been recognized. As a result most, if not all of the larger agricultural development projects in Mexico, as in many other countries, now make specific provisions for the supply of them. Typical of these comprehensive project packages is the Papaloapan Rural Development Project, which includes provisions and budgets for irrigation facilities, extension services, experimental farms, feeder roads, marketing facilities, incremental working capital, technical services, water sewerage, electricity, medical centers, schools and workshops, and community centers (see LaMadrid, 1975).

It is conceivable that all of these services will be delivered and will work and function as predicted, particularly if these new projects are financially well endowed so that they can outbid other competitors for the scarce professional input factors required. However, the problem in a macro-sense is precisely that these input factors are scarce and that they have many

\footnotetext{
*1 For the detailed description of yet another type of rural development program see LaMadrid (1975).

*2 In the short-run, of course, governmental expenditures in the form of wages to un- or underemployed agricultural workers can have an important impact on rural incomes.
} 
alternative employment opportunities. What this means is that the new projects, which have yet to be built, receive the scarce services that could not be supplied to projects or operations that are already in existence, and that would not require the expensive infrastructure investment of the new projects.

Hence, ceteris paribus, the marginal productivity of such a scarce input factor is much higher in an already existing project than in a new one. From an efficiency point of view (albeit not necessarily an equity point of view), therefore, its use in new projects is inferior to its use in projects which require less additional investment and other resources to match its own productive contribution.

As Schramm (1976) has estimated, even a sustained $10 \%$ per year increase in the output of trained agronomists and agricultural engineers in Mexico would not cover the estimated shortages of these professionals until shortly before the turn of the century. In 1974 there were some 2,851 extensionists active in the field (Bassoco de Gómez Tagle, 1975). The estimated requirements, however, were some 18,800 and growing because of the growing agricultural base. These shortages can be ameliorated to some extent. Under a new extension service system for small-scale dryland farmers, for example, the service of one trained agronomist is supplemented by up to five lowlevel, trained helpers. Whether this method will actually be successful remains to be seen however.

The inability to obtain the services of such skilled manpower is one of the major constraints facing more rapid agricultural development almost anywhere. This problem is world-wide, as many studies have shown (see e.g., Williams and Miller, 1973; Coombs and Manzor, 1974; Kirpich, 1976).

The importance of these human-skill based supporting services can be readily shown from the significant physical yield differentials between producers that are using available best practice as compared to those that achieve only average yields. Using a standard crop composition that reflects actual Mexican conditions (but excludes high-value crops such as fruits and vegetables for reasons discussed below) the data compiled in Table I show that net income per hectare of irrigated land, before accounting for irrigation investment costs, would amount to between approximately US $\$ 111$ to $\$ 282$ depending on the type of project, if average observed physical yields per hectare are obtained (at full labor costs). However, if projected yields would be achieved instead, income would rise to between $\$ 152$ and $\$ 329$ per hectare. Applying 1976 average irrigation investment costs per hectare, the internal rates of return are a low $4-5 \%$ at full labor costs, and $7 \%$ with a labor shadow wage rate of 0.7 if only average yields are achieved. With projected best practice yields, on the other hand, the internal rates of return increase to more respectable $10-11 \%$ and $12-13 \%$ ranges, respectively. Since projected yields are those that could be safely achieved with superior agricultural practice, it follows that management capabilities, rather than physical characteristics largely determine the economic viability of irrigation investments. 
TABLE I

Differences in average and potential agricultural yields and their effects on project rates of return (1976 costs and prices US $\$ 1.00=$ Mex. pesos 12.50)

(A) Basic data*1

\begin{tabular}{lllll}
\hline Crop & $\begin{array}{l}\text { Actual average } \\
\text { yield per ha } \\
\text { (tons) }\end{array}$ & $\begin{array}{l}\text { Projected average } \\
\text { yield per ha } \\
\text { (tons) }\end{array}$ & $\begin{array}{l}\text { Crop composition } \\
(\%)\end{array}$ & $\begin{array}{l}\text { Value of output } \\
\text { per ton } \\
\text { (US } \$ \text { ) }\end{array}$ \\
\hline Maize & 2.15 & 3.00 & 58.7 & 152.00 \\
Beans & 1.12 & 1.50 & 14.1 & 440.00 \\
Sorghum & 3.43 & 4.50 & 12.4 & 132.00 \\
Wheat & 2.67 & 4.00 & 8.5 & 144.00 \\
Alfalfa & 44.30 & 50.00 & 6.3 & 19.76 \\
Average & & - & 100.0 & - \\
per ha & - & & & \\
\hline
\end{tabular}

(B) Income and rates of return

\begin{tabular}{|c|c|c|c|c|c|}
\hline \multirow[t]{2}{*}{ Type of project } & & \multicolumn{2}{|c|}{ With full labor costs } & \multicolumn{2}{|c|}{$\begin{array}{l}\text { With } 0.7 \text { shadow } \\
\text { wage rate }\end{array}$} \\
\hline & & $\begin{array}{l}\text { actual } \\
\text { yields }\end{array}$ & $\begin{array}{l}\text { projected } \\
\text { yields }\end{array}$ & $\begin{array}{l}\text { actual } \\
\text { yields }\end{array}$ & $\begin{array}{l}\text { projected } \\
\text { yields }\end{array}$ \\
\hline \multirow[t]{3}{*}{$\begin{array}{l}\text { Tube-well } \\
\text { pump }\end{array}$} & $\begin{array}{l}\text { net income per } \\
\text { ha (US \$) }\end{array}$ & 111 & 282 & 152 & 329 \\
\hline & $\begin{array}{l}\text { investment costs } \\
\text { per ha (US \$) }\end{array}$ & 1,888 & & & \\
\hline & $\begin{array}{l}\text { internal rate of } \\
\text { return }(\%)\end{array}$ & 4 & 11 & 7 & 13 \\
\hline \multirow[t]{3}{*}{$\begin{array}{l}\text { Surface } \\
\text { reservoir }\end{array}$} & $\begin{array}{l}\text { net income per } \\
\text { ha (US \$) }\end{array}$ & 194 & 366 & 237 & 412 \\
\hline & $\begin{array}{l}\text { investment costs } \\
\text { (US \$) }\end{array}$ & 2,832 & & & \\
\hline & $\begin{array}{l}\text { internal rate of } \\
\text { return }(\%)\end{array}$ & 5 & 10 & 7 & 12 \\
\hline
\end{tabular}

*1 Based on Schramm (1977, tables 9 and 13).

*2 Actual average yields are those obtained in all small-scale irrigation projects in Mexico in $1974-1975$.

*3 Projected average yields represent the mid-range of those predicted for irrigation projects under construction in 1975-1976.

*4 Production costs for projects producing "projected" rather than average yields were increased by $10 \%$ to reflect higher input costs.

*5 Net income per hectare accounts for all input costs including water charges that cover operating and maintenance costs, except capital and interest costs for the irrigation investment. 
*6 Internal rates of return (IRR) are calculated assuming $20 \%$ less than average yields in
the first year, with full maturity reached in year 6 . If full-maturity yields could be ob-
tained in the first year, the deep-well IRR under projected yields would increase to 17
and $21 \%$ and the surface reservoir to 15 and $17 \%$, respectively.

What can be concluded from the data in Table I is that the net benefits from a successful extension and management service can be measured by the net difference in the internal rates of return between projects that produce only average, and others that actually achieve projected yields. In the above example, this difference amounts to 5 out of the $12 \%$ rate of return for a surface reservoir and 6 out of the $13 \%$ rate of return for tube-well pump projects.

Because of this crucial importance of the human skill, management-related input factors, and because of the very substantial lead-times required to properly train and produce such individuals, one of the most important strategies of long-term agricultural development is to devote more resources to training aspects, and somewhat less to the more immediate physical infrastructure type investments. While the latter will be much more visible, the former represent the real structural, long-term bottleneck that holds back agricultural output to levels substantially below existing potential.

\section{OUTPUT CONSTRAINTS}

Output constraints are basically market related. They occur, because hoped-for, predicted markets for certain crops do not materialize, or are available only at prices far below those predicted in the project planning stage.

These errors in forecasting are usually the result of a lack of integration of national, or market-wide projections of demand on the one hand, and an analysis of the totality of existing and potential supply from all sources on the other. Typically, in the evaluation of individual projects, the incremental effects of predicted new crop production on total available markets are studied, and, if they are relatively small, the conclusion is drawn that the additional supplies will have little or no effect on existing or projected market prices. No attention is given to the potential of other competing crop producing areas to increase their own supplies of the crop in question and to occupy the market niche that the project planner has reserved for the new project. This is particularly true for the so-called high-value, but also highrisk, crops such as fruits, vegetables, cotton, coffee and others. The following analysis of eight large irrigation projects in Mexico will illustrate the problem.

Table II shows a comparison of some of the projected characteristics of the above-mentioned eight projects with those of all existing irrigation districts of $1973-1974$. As can be seen, the total irrigated area of the new projects was projected to be equal to almost $21 \%$ of the area harvested (including double-cropping) of all existing districts in 1973-1974. Predicted average gross income per hectare (in constant prices) was $\sim 23 \%$ higher than income 


\section{TABLE II}

Projected characteristics of eight new compared to all existing irrigation districts, 1973/74 crop year and projected ${ }^{* 1}$ (from S.R.H., 1975 and various unpublished reports)

$\begin{array}{lll}\begin{array}{l}\text { New } \\ \text { projects }\end{array} & \begin{array}{l}\text { Existing } \\ \text { districts }\end{array} & \begin{array}{l}\text { New projects as } \\ \text { a percent of } \\ \text { existing districts }\end{array}\end{array}$

Total area irrigated

hectares harvested

$611.100 \quad 2,972.093 \quad 20.6$

Percent of area dedicated to fruits and vegetables

$\begin{array}{lll}8.3 & 5.2 & 32.6\end{array}$

Percent of area dedicated to cotton

$\begin{array}{lll}14.7 & 15.2 & 19.6\end{array}$

Average gross income per ha, all crops (US \$)

754.40

611.11

123.4

Average gross income per ha, fruits and vegetables (US\$)

$\begin{array}{lll}2,257.30 & 1,728.43 & 130.6\end{array}$

Average gross income per ha, cotton (US \$)

$\begin{array}{lll}806.67 & 928.06 & 86.9\end{array}$

Average gross income per ha, all crops except fruits, vegetables and cotton (US \$)

582.27

477.05

122.1

Percent of total gross income generated by fruits and vegetables

24.8

14.8

Percent of total gross income generated by cotton

$$
23.0
$$

Total average net income per ha of fruits and vegetables (US \$)

$\begin{aligned} 1,462.40 & \text { n.a. }{ }^{* 2} \\ 425.60 & \text { n.a. }{ }^{* 2} \\ 223.20 & \text { n.a. }^{* 2}\end{aligned}$

Total average net income per ha of cotton (US \$)

Total average net income per ha of all other crops (US \$)

n.a.

*1 Exchange rate US $\$ 1.00=$ Mex. pesos 12.50. For the existing districts income refers to average during 1973-1974. For the new projects data refer to projected income at full maturity in constant, base-year prices.

*2 n.a. = not available.

realized in existing districts. This presumed increase in net income was the result of, (1) higher assumed yields per hectare for almost all crops; and (2) and more importantly, the result of projected crop compositions that varied significantly from those observed in existing districts. While the latter produced fruits and vegetables on only $\sim 5.2 \%$ of the land, the new projects were projected to dedicate $8.3 \%$ of their area to these potentially high value crops. In addition, $\sim 14.7 \%$ of the land was predicted to be planted 
with cotton, another high-value crop, compared to $15.2 \%$ in existing districts $^{* 1}$. These projected cropping patterns would have resulted in an overall net increase in the area of land producing fruit and vegetables by $32.6 \%$ (compared to $1973-1974^{* 2}$ ) and producing cotton by $19.6 \%$. As will be shown below, these projections appear to be far too optimistic.

Inclusion of fruits, vegetables and cotton in predicted cropping patterns seemingly is rather attractive from an economic point of view. Both average gross and net incomes rise significantly. Predicted gross income per hectare for fruits and vegetables was $\$ 2,257.30$. This compares to an average of $\$ 582.27$ if these higher-value crops were to be excluded. Not surprisingly, then, the $8.3 \%$ of land allocated to fruits and vegetables would account for $24.8 \%$ of total gross, and an even more impressive $33.4 \%$ of total net income (last percentage not shown in Table II). Cotton, with $14.7 \%$ of the area, would account for another $17.5 \%$ of gross and $17.2 \%$ of net income if these predictions were realistic. The farmer who would manage to put his land into fruits and vegetables seemingly would be handsomely rewarded, since his net income per hectare would increase from $\$ 223.30$ to $\$ 1,462.40$, or by some $655 \%$. For cotton, these differentials would be more modest, but still amount to an impressive $91 \%$ gain.

The question to be asked is why farmers in already existing districts do not seize the opportunity for switching from low-value, low-net return crops to those that are apparently so much more profitable. While lack of knowledge, distance to markets, production risks from pests, lack of peak-load farm labor, and climatological or soil factors all play some role, the real answer to this question is that viable, reasonably secure markets for significant increases in output of these high-value crops do not exist. While these crops, potentially, have a high market value, and while, potentially, they could reward the grower with high income per hectare, they also face substantial marketing risks from highly volatile prices. This becomes quite apparent from an analysis of the domestic and export markets for Mexican fruits, vegetables and cotton.

\section{Domestic markets for fruit and vegetables}

It is estimated that some $60 \%$ of Mexico's domestically marketed vegetable and fruit productions pass through Mexico City's wholesale market. The City's wholesale prices, therefore, provide a good indication of overall marketing conditions. Table III shows the range of weekly price fluctuations

\footnotetext{
*1 These two percentages are roughly the same since some of the eight projects were climatically unsuited for cotton production.

*2 Relative to irrigation districts only. Substantive amounts of these crops are also grown in small-scale irrigation units or on privately irrigated land. The total irrigated acreage amounted to $\sim 5 \cdot 10^{6}$ ha.
} 
TABLE III

Range of weekly whole-sale prices of fresh vegetables, Mexico, January-February, 1975 (from S.A.G., 1975)

\begin{tabular}{llll} 
& \multicolumn{2}{c}{ (Mex. pesos per kg) } & Ratio low/high \\
\cline { 2 - 3 } & high & low & \\
\hline Onions & 2.20 & 1.48 & 0.67 \\
Garlic & 5.27 & 3.83 & 0.73 \\
Tomatoes & 5.71 & 3.20 & 0.56 \\
Chile, green & 8.10 & 3.57 & 0.44 \\
Beans, green & 4.69 & 1.85 & 0.39 \\
Peas, green & 5.51 & 2.82 & 0.51 \\
\hline
\end{tabular}

for a number of fresh vegetable staples during a two-month period in 1975. As can be seen, price fluctuations are large and range from a low/high ratio of $39 \%$ for green beans, a relatively quickly perishable crop, to $73 \%$ for garlic, a commodity with a long unrefrigerated storage life. On an annual basis, these daily and weekly price fluctuations are even larger and exceed for major products their mean annual price level. What these sharp fluctuations indicate is that marketing risks are high, and that, depending on alternative sources of supply that may come on the market the same day, or depending on fluctuations in demand, gross revenues to the producer may fall by $50 \%$ and more.

These drastic price changes are largely unpredictable, even on an overall seasonal basis. This can be seen from Fig. 1 which shows monthly average Mexico City wholesale prices for red, round tomatoes (the single most important vegetable crop marketed). Current prices between April and September, 1975 were significantly lower than those in 1974, and that in spite of a general inflation rate well in excess of $20 \%$ per year. Furthermore, both in 1974 and 1976 monthly price levels were highest during the same period, while in 1975 they were the lowest, compared to the rest of the year. In other words, seasonal price fluctuations worked in quite different directions from one year to the next in three successive years. One likely reason for this seasonal unpredictability is that there are many growers, in many areas, and that climatic zones in Mexico are such that almost any crop can be grown somewhere at any time of the year. Many potential suppliers will enter or leave the market on a rather volatile basis, depending on their past success or failure or their future price expectations.

But it is nevertheless true that the potential gain from fruit and vegetable production in periods of medium to high prices is higher than the gain from lower-valued crops such as grains. As a result, the markets are frequently in an oversupply situation. For example, regression analysis of average monthly 


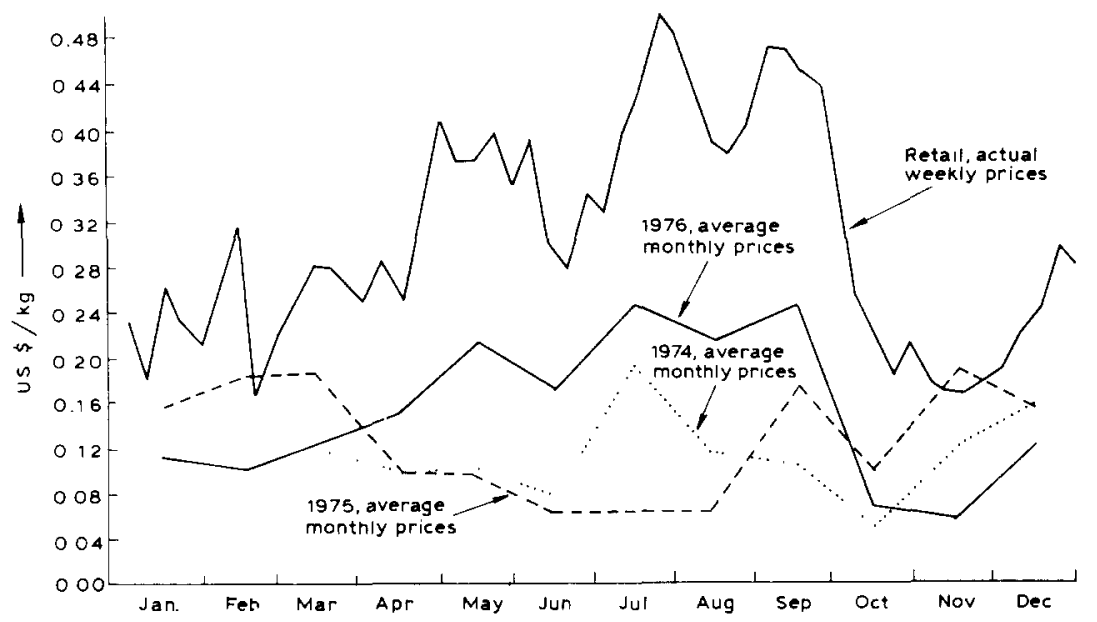

Fig. 1. Daily 1976 retail market prices, and 1974,1975 and 1976 average monthly wholesale prices, red round tomatoes, La Merced market, Mexico City in current US $\$$, US $\$ 1.00=12.50$ Mex. pesos (from S.A.G., 1976).

wholesale tomato prices in constant terms during the period of $1974-1976$ *1 showed that in the majority of the 33 observed periods more tomatoes were sold than would have been rational from an overall profit-maximizing point of view, i.e. transactions took place in the inelastic range of the estimated demand function. What this means is that total revenue to all sellers would have increased if supplies had been lower*2.

One of the consequences of such a continuous oversupply situation is that eventually a number of growers will turn to less volatile, lower-valued crops. This seems to have been the case in Mexico in recent years. In absolute quantities, the supplies of short-cycle crops actually declined since 1974. This is the result of a continuous cost squeeze, with farmgate prices increasing at slower rates than the rapidly increasing rate of inflation since 1972-1973. Only for long-cycle crops (generally tree-fruits) did supplies remain steady or increased slightly. This is to be expected, since these growers are locked into production from long-life assets (e.g., trees) for as long as out-of-pocket production and harvesting costs are lower than farmgate prices $^{* 3}$.

\footnotetext{
*1 The 1974-1976 regression equation took the form of : (price) $=$ US $\$ 449.28-$ US $\$ 0.0216$ (ton)

monthly quantities sold ranged from 6,200 to over 17,000 tons, with above 10,400 tons being transacted in the inelastic range of the demand function.

*2 It also means, however, that the often rumored tight market control of Mexico City's dominant wholesale merchants is less monopolistic than is generally assumed.

*3 Between 1972 and 1976 the index of market prices for vegetables increased from 120 to 220 , and for short-cycle fruits from 100 to $182(1970=100)$. For long-cycle fruits, prices rose only from 95 to 150 . These divergent price trends were a result of changing market supplies. Both vegetables and short-cycle fruits declined after 1974, from 150 to 120 for the former and from 110 to 90 on a composite tonnage basis. Long-cycle fruit supplies, on the other hand, increased from 120 to 138 (data from S.A.G., 1976).
} 
Mexico is the dominant winter-season import supplier of fresh fruits and vegetables to the U.S.A. and Canada. Its major competitor is Florida. As can be seen from Table IV, the Mexican share of total supplies ranges from $36 \%$ for bell peppers to $81 \%$ for fresh strawberries. Supplying fruits and vegetables for exports is very attractive since farmgate prices are far higher than prices obtainable in the domestic market. This is quite apparent from the data shown in Table $\mathrm{V}$, which show farmgate prices for export crops and the lowest average farmgate prices for districts selling exclusively in the domestic market.

However, export markets are strictly limited to the winter season. For a variety of cost-related reasons Mexico is not competitive with U.S. growers during the spring-summer and fall seasons. It is also unable to compete in the quantitatively much larger, but much lower-priced U.S. and Canadian canned and frozen vegetable and fruit markets, with the single exception of frozen or canned strawberries and some tropical fruits.

Unfortunately, these export markets are also rather limited in quantitative terms. U.S. per capita fresh fruit and vegetable consumption has been stagnant or declined in recent decades. Between 1960-1962 and 1973-1975 average U.S. per capita consumption fell by $4 \%$, while frozen and canned consumption increased by 38 and $24 \%$, respectively. It is not surprising, then, that Mexico's exports, after rapid advances in the 1960's when they established themselves firmly in the U.S. and Canadian off-season markets, began to stagnate. Overall, exports began to fall in constant dollar terms after 1972 to about $2 / 3$ of former levels. The outlook for the future is for wide year-toyear swings, depending on Florida's harvesting conditions which are subject to recurring frost damage. However, total market demand will expand very little, and it has been estimated that the total increase in acreage required to accommodate the incremental U.S. market demand over the next ten years

\section{TABLE IV}

Mexican and Florida market shares of the U.S. fresh winter vegetable and fruit markets 1973-1974 crop year (from Simmons et al., 1976)

\begin{tabular}{lll}
\hline Product & \multicolumn{2}{l}{ Market share } \\
\cline { 2 - 3 } & Mexico & Florida \\
\hline Tomatoes & 49 & 51 \\
Strawberries & 81 & 18 \\
Cucumbers & 46 & 54 \\
Bell Peppers & 36 & 64 \\
Eggplant & 53 & 47 \\
\hline
\end{tabular}


TABLE V

Inter-district average farmgate price ranges for selected crops 1973-1974 crop year (from S.R.H., 1975)

\begin{tabular}{llrrr}
\hline Crop & District & $\begin{array}{l}\text { Hectares } \\
\text { harvested } \\
\text { HAS }\end{array}$ & $\begin{array}{l}\text { Price per } \\
\text { ton } \\
\text { (US \$) }\end{array}$ & $\begin{array}{l}\text { Ratio } \\
\text { high/low }\end{array}$ \\
\hline \multirow{3}{*}{ Squash } & Valle de Fuerte, Sin. & 612 & 385.00 & 5.8 \\
Onions & Alto Rio Lerma, Gto. & 105 & 66.56 & \\
& Estado de Morelos, & 109 & 205.12 & 6.4 \\
Green chile & C. de Chapala, Mich. & 101 & 32.00 & \\
& Rio Mayo, Son. & 899 & 800.00 & 8.3 \\
Trujillo, Zac. & 208 & 96.00 & \\
& Valle de Fuerte, Sin. & 1,002 & 412.48 & 6.6 \\
Okra & Penitas, Col. & 150 & 64.00 & \\
& Bajo Rio Bravo & 2,646 & 175.44 & 1.7 \\
Green peas & Laguna de Tuxpan, Gro. & 110 & 103.92 & \\
& Culiacan, Sin. & 102 & 265.12 & 2.8 \\
& Rio Mayo, Son. & 1,066 & 96.00 & \\
Cantaloupe & Valle de Guaymas, Son. & 323 & 208.00 & 4.3 \\
& R. Amuco y Cutzamala, Gro. & 201 & 48.00 & \\
Cucumbers & Valle de Fuerte, Sin. & 140 & 539.84 & 7.5 \\
& Tepalcatepec, Mich. & 874 & 72.00 & \\
\hline
\end{tabular}

${ }^{\star 1}$ Limited to districts with a minimum of 100 ha harvested of the particular crop.

Col. = Coahuila ; Gro. = Guerrero; Gto. = Guanjuato; Mich. = Michoacan; Sin. = Sinaloa; Son. $=$ Sonora $;$ Zac. $=$ Zacatecas.

will be between 30,000 and 35,000 ha. Of that, only $3000-4000$ ha are required to supply the predicted demand for fresh winter vegetables. For Mexico, for all practical purposes, this means that no additional acreage will be needed to supply whatever market share it can obtain and hold.

Given the potential profitability of these export markets for Mexican growers on the one hand and the quantitatively strictly limited and highly inelastic market demand on the other*1, Mexican exporters, through their government-supported trade associations*2, maintain tight control over quantities supplied to border crossing points. Rationing of supplies whenever needed is a way of life to these highly sophisticated Mexican producers.

\footnotetext{
*1 Typically, Mexican export farmgate prices amount to only $20-25 \%$ of the duty-paid value at the U.S.A. border. In terms of supermarket shelf prices, this percentage is around $5 \%$. Given these price relationships it is clear that reductions in Mexican farmgate prices will have no effect on quantities sold, except to the extent that Florida producers are displaced from a given regional market.

*2 For a detailed discussion of the operation of these associations see Andrew (1975).
} 


\section{Cotton}

Mexico is one of the world's leading cotton producers. Except for some rather stable 20,000-30,000 producing hectares under dry-land farming conditions in south Mexico, almost all cotton is grown under irrigation in northern and northwestern Mexico. Production reached its peak in the late 1950 's when more than 600,000 ha of irrigated land in S.R.H. districts alone were devoted to this crop. Since then the area planted has declined substantially. On the other hand, yields per hectare have risen, offsetting in part the decline in area. Recent years have seen sharp fluctuations in production as a consequence of world market price developments. In 1974-1975, for example, the area planted in S.R.H. districts fell to 185,000 from 450,000 ha in the previous year. Since then, production has recovered again, with 239,000 ha $(198,000$ in districts) planted in 1976-1977 and 358,000 (318,000 in districts) in 1977-1978. Total 1976-1977 output was about one million bales in $76 / 77$ and is expected to reach almost 1.5 million in $77 / 78$.

What these developments show is that there is a large potential in existing areas for increased production. When market conditions are favorable, output increases rapidly, but it declines equally rapidly when prices deteriorate, as they did in 1973-1974. From an investment point of view, it can be concluded that no new areas, irrigated or temporal, are needed in order to facilitate greater production.

\section{Implications for project planning}

What must be concluded from this analysis of output constraints is that inclusion of so-called high-value and apparently high income producing crops in new irrigation projects is either illusory and will not occur in reality, or if these crops are really going to be planted under the prodding of the respective government planning agency, from a national point of view this would simply mean a displacement of already existing potential production elsewhere.

\section{SOME POLICY CONCLUSIONS}

The findings of this study point towards the need for revision of a number of presently applied program and project evaluation criteria.

(1) In countries such as Mexico, where climatic and ecological conditions make it possible to grow a wide variety of both high- and low-value crops on existing irrigated land, but where the latter predominate, new projects should generally be evaluated on the basis of low-value crop production only. 
(2) Where high-value, and by implication, high-net-income crops are included, this inclusion should be specifically justified on the basis of unique factors that make the particular project superior to already existing ones.

(3) Expected price levels for all specialty crops should be based on observed price levels in the local or regional markets to be served, not on price levels in the highest-value national or export markets or on national averages. Moreover these price levels have to be based on observed seasonal market prices, given the wide swings of the latter. Prices for perishable crops that are subject to wide, daily variations should be based on the lower end of the scale, since the additional income from temporary, high market prices are likely to benefit mainly the middleman, but not the farmer.

(4) Detailed studies should be undertaken on an ongoing basis to estimate from year to year the likely growth in demand for higher-value crops in both domestic and export markets. The studies should relate seasonal timing to likely price elasticities of demand in the various (regional) sub-markets. These projections could then be used to assess in a more realistic fashion the actual market potential and likely profitability of these crops.

(5) In new projects, superior farm management capabilities are unlikely to be found among the project's beneficiaries. Hence, education, e.g. extension, demonstration plots, organization, fertilizers, credit and all other required inputs are an absolute necessity to bring about the economically required superior yields per hectare. Many of these inputs, particularly those involving technical assistance, are in chronically short supplies. Hence the opportunity costs of these inputs, as measured by their potential net productivity elsewhere, is also high, higher presumably than their costs of supply (i.e. their wage rate). Hence, it is not only necessary in project planning to allow for these input factors, but to (a) assure their physical availability in a timely fashion and (b) to evaluate their true economic costs in terms of their foregone net productivity elsewhere.

\section{ACKNOWLEDGEMENTS}

The author wishes to thank M. Ballesteros, J.R. Cunningham, M. Escamilla, S.I. Friedmann, F.G. Gonzalez V., D.P. Hughart, P.Z. Kirpich, J.E. Link, C. Moret, C.W. Porter, A. Schumacher and L.M. Wilson whose comments and discussions at various occasions helped him to formulate the ideas expressed in this paper. However, none of them necessarily concurs with the conclusions drawn which are strictly the author's own responsibility.

\section{REFERENCES}

Adelman, I. and Morris, C., 1967. Society, Politics, and Economic Development. Johns Hopkins Press, Baltimore, Md. (rev. ed. 1971). 
Andrew, C.O., 1975. Mexican winter vegetable production, marketing and trade - An overview. Food Resour. Dep., Univ. Fla., Gainesville, Florida, Fla.

Bassoco de Gómez Tagle, L.M., 1975. Analisis de la contribucion de los factores e insumos de la produccion al crecimiento del sector agricola de 1970 y 1974. Com. Coord. Sect. Agropec. (C.O.C.O.S.A.) Mexico City, Nota Tech. No. 5.

Coombs, P. and Manzor, A., 1974. Attacking Rural Poverty: How Nonformal Education Can Help. Johns Hopkins Press, Baltimore, Md.

Escamilla, M., Schramm, G. and Gonzales V., F.G., 1975. Water as a social solvent? Alternative development strategies for Mexico's subsistence agricultural sector. Proc. 2nd World Congr., Inter. Water Resour. Assoc., New Delhi, pp. 571-588.

Kirpich, P.Z., 1976. Leadership constraint in project preparation. Am. Soc. Civ. Eng., Eng. Iss., 102: 417-422.

LaMadrid, A., 1975. Integrated rural development project for the Papaloapan Basin in Mexico. Proc. 2nd World Congr., Inter. Water Resour. Assoc., New Delhi, pp. 519527.

Pearson, J.L., 1974. Costs and factors affecting production of fresh tomatoes, peppers and cucumbers in Florida and west Mexico for U.S. markets. In: The Vegetable Situation. U.S. Department of Agriculture, Washington, D.C.

S.A.G. (Secretaría de Agricultura y Ganadería), 1975. Secr. Agric. Ganad., Mexico City, Bol. Interno (various issues).

S.A.G. (Secretaria de Agricultura y Ganadería), 1976. Secr. Agric. Ganad., Mexico City, Bol. Interno.

Schramm, G., 1972. The design of a resource allocation function. Can. J. Econ., 5(4): $515-530$.

Schramm, G., 1977. Micro versus macro considerations in irrigation planning. Pap. presented at 16th Annu. Meet. W. Reg. Sci. Assoc., Tucson, Ariz. (mimeographed).

Schramm, G., 1976. Human-institutional factors in water management in the developing countries. Nat. Resour. J., 16(4): 925-937.

Simmons, R.L., Pearson, J.L. and Smith, E.B., 1976. Mexican competition for the U.S. fresh winter vegetable market. U.S. Dep. Agric., Washington, D.C., Econ. Res. Serv. Rep. No. 348.

S.R.H. (Secretaria de Recursos Hidráulicos), 1975. Estadistica agricola del ciclo 1973/ 1974. Secr. Recurs. Hidrául., Mexico City.

Urquidi, V.L., 1974. Empleo y explosión demografica. Demogr. Econ., B(2): 141-153.

Williams, S. and Miller, J., 1973. Credit Systems for Small Farmers. University of Texas Press, Austin, Texas. 